\title{
PENDAPATAN USAHATANI KERBAU BANPRES DI PROPINSI DAERAH ISTIMEWA YOGYAKARTA
}

\section{ABSTRAK.}

Tujuan penelitian untuk mengetahui pendapatan usahatani kerbau Banpres, tingkat managerial skill dan kemampuan pengambilan gaduhan ditinjau dari segi ekonomi enam puluh petani responden di setiap Kabupaten Bantul, Kabupaten Kulon Progo dan Kabupaten Sieman Daerah Istimewa Yogyakarta yang mendapatkan gaduhan kerbau gaduhan. Penelitian dilaksanakan mulai 10 Februari 1988 sampai 15 Juni 1988. Data yang diperoleh dianalisis secara input-output. Untuk menghitung pendapatan usahataninya Analisis Efisiensi Usaha, PPC untuk mengetahui waktu pengambilan ternak gaduhan,serta analisis managerial skill untuk mengetahui kemampuan mengelola usahatani ternak kerbau.

Hasil penelitian menunjukkan pendapatan usahatani kerbau di Kabupaten Kulon Progo tertinggi Rp. 96.666,atau Rp 29.013,- per ekor disusul Kabupaten Bantul Rp. 96.061,- atau Rp 28.972,- per ekor dan terkecil di Kabupaten Sleman Rp 70.214,- atau Rp 26.051,-- per ekor. Efisiensi usaha masing-masing untuk Kabupaten Bantul, Kulon Progo dan Sleman yaitu $10,32 \% ; 11,73 \% ; 9,02 \%$; dengan PPC masing-masing 9,3 tahun; 9,1 tahun; 10,1 tahun, yang berarti belum mampu mengembalikan, ternak gaduhan dalam jangka waktu 6 tahun (Perjanjian). Managerial skill nilai score masing-masing Kabupaten Bantul, Kulon Progo dan Sleman yaitu : 67,32;62;02 dan 57,82 menunjukkan masih belum baik pengelolaan usahatani kerbaunya.

*) Staf pengajar jurusan Sosial Ekonomi Fakultas Peternakan Universitas Gadjah Mada.

\section{PENDAHULUAN}

Pada umumnya kerbau diternakkan bukan dengan tujuan penghasil daging, akan tetapi dipelihara oleh petani secara tradisional untuk dimanfaatkan tenaga kerja dan pupuknya. Di daerah pertanian yang berlumpur atau sawah, kerbau sangat cocok dikerjakan dan mempunyai peranan yang penting - bagi petani. Menurut Usman (1971) rata-rata pemilikan kerbau oleh petani sekitar dua ekor bahkan sering diketemukan (Hutasoit, 1973) petani hanya memelihara beberapa ekor kerbau milik orang lain atau pemerintah dengan cara bagi hasil atau upah tertentu (gaduhan). kadang-kadang dijumpai umur ternak kerbau yang dipelihara sampai tua tetap dipertahankan asalkan masih mampu untuk bekerja ke sawah (Wiryosuhanto, et al, 1980). Keterbatasan modal kerja yang dimiliki petani, menyulitkan pemilikan kerbau, sehingga pemerintah memberi bantuan melalui gaduhan kerbau Banpres.

Tujuan pemerintah memberikan bantuan ternak kerbau kepada petani yaitu untuk mempercepat pengembangan dan pemerataan pemilikan ternak sekaligus meningkatkan pendapatan petani. Disadari pula sejak Pelita I sampai Pelita IV populasi ternak kerbau di Indonesia kenaikannya sangat rendah kurang dari dua persen sehingga bantuan kerbau Banpres didatangkan (impor) dari Australia bantuan ternak kerbau secara gaduhan diberikan dalam bentuk paket yang terdiri dari seekor betina ataupun pejantan umur dua tahun sampai dua setengah tahun (Anonimus, 1985). Sasaran paket ini diutamakan masyarakat tani yang melakukan usahatani ternak secara tradisional dengan persyaratan mempunyai pengalaman beternak kerbau, menyediakan kandang dan memelihara dengan baik serta bersedia mengikuti petunjuk teknis dan bimbingan teknis dari Dinas Peternakan. Di daerah Istimewa Yogyakarta bantuan kerbau Banpres berada di tiga kabupaten yaitu Kabupaten Bantul, Kabupaten Kulon Progo dan Kabupaten 
Sleman. Penelitian ini bertujuan untuk mengetahui pendapatan usahatani kerbau Banpres, tingkat managerial skill, serta kemampuan pengembalian gaduhan ditinjau dari segi ekonomi.

\section{MATERI DAN METODE}

Obyek yang diteliti adalah petani yang memiliki kerbau Banpres di Kabupaten Dati II Bantul, Kulon Progo dan Sleman. Kecamatan dipilih adalah yang memiliki kerbau Banpres terbanyak. Responden dipilih secara acak lengkap sebanyak 20 orang di setiap kecamatan yang terpilih.

Tabel 1. : Jumlah sampel dari lokasi.

\begin{tabular}{llcc}
\hline Kabupaten & Kecamatan & Yang tersedia & Sampel \\
\hline Bantul & Srandakan & 47 & 20 \\
& Pundong & 32 & 20 \\
\multirow{5}{*}{ Kulon Progo } & Sedayu & 44 & 20 \\
& Galur & 48 & 20 \\
& Lendah & 49 & 20 \\
\multirow{5}{*}{ Sleman } & Kalibawang & 50 & 20 \\
& Seyegan & 43 & 20 \\
& Tempel & 36 & 20 \\
& Minggir & 39 & 20 \\
\hline
\end{tabular}

Metoda yang digunakan adalah survai ke lapangan dengan menggunakan kuesioner yang telah disiapkan. Penelitian dilakukan lima bulan, mulai 10 Februari 1988 sampai 15 Juni 1988. Parameter yang diukur meliputi : identitas petani, motivasi beternak, pemilikan ternak, masukan seperti nilai kandang, gudang, tempat pakan, sepeda bajak, penerangan dan alat lain yang digunakan dalam pemeliharaan kerbau, pakan, tenaga kerja.

Hasil atau nilai keluaran meliputikotoran, nilai tambah dari ternak.. Analisis yang digunakan adalah input-output untuk usahatani kerbau dan tingkat managerial skill berdasarkan 10 unsur sifat manager yang baik. Rata-rata pendapatan usahatani diuji dengan analisa varian terhadap perbedaan lokasi yang selanjutnya bila berbeda nyata diuji kembali dengan DMRT (Astuti, 1980).

\section{HASIL DAN PEMBAHASAN}

Umur rata-rata peternak diketiga kabupaten tidak begitu berbeda yaitu sekitar 43,59 tahun. Umur tersebut masih mempunyai kemampuan untuk berfikir dan bertindak secara hati-hati, sehingga diharapkan dapat mengembangkan usahatani kerbau pada waktu yang akan datang. Sedangkan pengalaman memelihara ternak kerbau rata-rata 16.03 tahun di mana peternak Kabupaten Sleman mempunyai pengalaman tertinggi yaitu 21,62 tahun.

Menurut Koentjaraningrat (1969) pengalaman merupakan salah satu faktor yang dapat menentukan maju mundurnya suatu usaha. Ternyata masih ada $14,99 \%$ responden yang belum pernah memelihara ternak kerbau. Ini menyulitkan pengembangan-pengembangan usahatani kerbaunya. Di sisi yang lain masih terdapat sekitar $29,44 \%$ responden yang belum mendapatkan pendidikan (butahuruf), bahkan yang mengenyam di bangku SD cukup besar yaitu $56,11 \%$. Ditinjau dari motivasi beternak ternyata petani pemilik kerbau lebih mengutamakan untuk menunjang usahatani sawah sebagai penarik bajak $(48,33 \%)$, bahkan di Kabupaten Bantul lebih dari separo $(56,66 \%)$ petani mempunyai motivasi memiliki kerbau untuk membajak sawahnya.

Tabel 2. Rata-rata umur, pengalaman, pendidikan dan motivasi beternak di daerah penelitian.

\begin{tabular}{l|rrrr}
\hline \multirow{2}{*}{ U r a i a n } & \multicolumn{3}{|c|}{ Kabupaten } & \multirow{2}{*}{$\begin{array}{l}\text { Rata- } \\
\text { rata }\end{array}$} \\
\cline { 2 - 5 } & Bantul & KIProgo & Sieman & \\
\hline 1. Jumlah sampel (n) & 60 & 60 & 60 & 60 \\
2. Rata-rata umur pe- & & & & \\
ternak (tahun) & 43,72 & 48,33 & 44,74 & 43,59 \\
3. Pengalaman beternak & & & & \\
yang telah berpengala- & & & & \\
man (\%) & 15,25 & 11,21 & 21,62 & 16,03 \\
yang belum (\%) & 13,33 & 15,00 & 16,66 & 14,99 \\
4. Pendidikan (\%) & & & & \\
Buta huruf & 35,00 & 31,66 & 21,66 & 29,44 \\
SD & 51,66 & 56,66 & 60,00 & 56,11 \\
SLTP & 8,34 & 8,34 & 15.00 & 10,56 \\
SLTA & 5,00 & 3,34 & 3,34 & 3,89 \\
5. Motivasi beternak (\%) & & & & \\
Membajak & 56,66 & 51,66 & 36,66 & 48,33 \\
Tabungan & 21,67 & 38,34 & 55,00 & 38,34 \\
Dikembangbiakan & 21,67 & 10,00 & 8,34 & 13,33
\end{tabular}

Namun demikian masih dijumpai ternak kerbau yang belum dapat mengerjakan sawah $(21,66 \%)$, sedangkan yang masih taraf diajar meliputi $11,66 \%$ dan sisanya $66,68 \%$ yang mampu mengerjakan sawah.

Dari analisis pendapatan usahatani di tiga kabupaten menunjukkan bahwa pendapatan peternak kerbau di Kabupaten Kulon Progo terbesar (Rp. 96.666,-) meskipun 
tidak berbeda nyata dengan pendapatan peternak di Kabupaten Bantul (Rp.96.061). Sedangkan pendapatan peternakan di Kabupaten Sleman (Rp 70.204,-) berbeda sangat nyata baik Kabupaten Bantul maupun Kabupaten Kulon Progo. Hal ini dipengaruhi oleh nilai pupuk per kilogram lebih tinggi dan jumlah sawah yang disewakan tenaga kerja ternaknya lebih besar di kedua Kabupaten Bantul dan Kulon Progo dibanding Kabupaten Sleman.

Demikian pula kalau dilihat pendapatan usahatani per ekor,Kabupaten Kulon Progo terbesar (Rp 29.013,-) kemudian disusul Kabupaten Bantul (Rp. 28.972,-) dan yang terkecil Kabupaten Sleman (Rp. 26.051). Hasil perhitungan efisiensi usaha juga menunjukkan Kabupaten Kulon Progo terbesar yaitu $11,73 \%$ kemudian disusul Kabupaten Bantul 10,32\% dan yang terkecil adalah Kabupaten Sleman $9,02 \%$. Penggunaan modal belum efisien baru terserap hanya $10,36 \%$, masih terlalu besar investasi yang ditanamkan. Keadaan kandang, gudang yang relatif tinggi menyebabkan pemborosan dalam penanaman modal. Apabila dibandingkan dengan tingkat bunga tabungan yang berlaku ( $15 \%$ per tahun) masih kurang menguntungkan investasi modal pada usahatani kerbau.

Analisis PPC yang menunjukkan rata-rata 9,5 tahun berarti apabila peternakan meminjam uang dari Bank baru akan kembali, 9,5 tahun yang akan datang. Padahal perjanjian penggaduhan menyatakan peternak harus melunasi dalam jangka waktu 6 tahun dan ini kemungkinan sulit dapat dicapai. Faktor-faktor yang mempengaruhi adalah mundurnya kebuntingan atau belum bunting, disamping ternak masih setengah liar sehingga untuk memperoleh anakpun akan tertunda pula. Pada saat penelitian ternak yang bunting di Kabupaten Bantul, Kulon Progo dan Sleman sebagai berikut $12,35 \% ; 17,33 \% ; 18,06 \%$.

Faktor managerial skill dari 10 unsur yang dinilai secara rata-rata masih rendah yaitu 62,72 (cukup) di mana Ka-

Tabel 3.: Rata-rata Total Biaya, Pendapatan Kotor, Pendapatan Bersih dari Usahatani Kerbau (Rp).

\begin{tabular}{lrrrrr}
\hline \multirow{2}{*}{ U r a i a n } & \multicolumn{3}{c}{ Kabupaten } & \\
\cline { 2 - 5 } & Bantul & Kulon Progo & Sleman & $\begin{array}{r}\text { Rata- } \\
\text { rata. }\end{array}$ \\
\cline { 2 - 5 } & & & & & \\
Pendapatan Kotor (Rp) & 129.732 & 139.333 & 109.971 & 126.345 \\
Toral Biaya (Rp) & 33.671 & 42.667 & 39.754 & 38.697 \\
Pendapatan Bersih (Rp) & 96.061 & 96.666 & 70.214 & 87.648 \\
Pendapatan/ekor (Rp) & 28.972 & 29.013 & 26.051 & 28.012 \\
Efisiensi Usaha (\%) & 10,32 & 11,73 & 9,02 & 10,36 \\
PPC (Tahun) & 9,10 & 9,10 & 10,10 & 9,50 \\
& & & & & \\
\hline
\end{tabular}

bupaten Bantul terlihat lebih trampil dalam mengelola ternak kerbau $(67,32)$. Sedangkan di Kabupaten Kulon Progo mendapat nilai 63,02 dan Kabupaten Sleman 57,82. Hal ini erat kaitannya dengan faktor pendidikan yang rendah, kurang mendapat penyuluhan dan motivasi beternak, sehingga cara mengelola ternak masih belum beranjak dari tradisional

\section{KESIMPULAN}

Berdasarkan hasil penclitian dapat disimpulkan petani meminta gaduhan kerbau Banpres atas dasar motivasi untuk membantu mengerjakan sawah $(48,33 \%)$, sedangkan tabungan hanya $38,34 \%$ dan sisanya bermotivasi dikembangkan $(13,33 \%)$. Pendapatan usahatani yang diperoleh rata-rata $R p$ 87.648,- atau per ekor $R p 28.012$,- di mana PPC 9,50 tahun yang berarti sulit mengembalikan dalam batas 6 tahun dari perjanjian gaduhan.

Efisiensi usaha yang relatif rendah $(10,36 \%)$ menunjukkan belum mampu mengelola usahatani kerbau secara baik.

Saran

Perlu penyuluhan yang berkesinambungan agar peternak mengelola usahatani kerbaunya. Perlu dipertimbangkan waktu gaduhan yang 6 tahun mengingat PPC : 9,5 tahun.

\section{DAFTAR PUSTAKA}

Anonimus, 1985, Pedoman Umum Pelaksanaan Bantuan Pemerintah, Ditjenak, Jakarta.

Astuti M., 1980, Rancangan Percobaan dan Analisa Statistik Bagian Pemuliaan Ternak, Fakultas Peter nakan UGM, Yogyakarta.

Hutasoit J., 1973, Perspektif Peternakan di Indonesia, Ditjennak Deptan, Jakarta.

Koentjaraningrat, 1969, Kerangka untuk Meneliti Faktor faktor Sosial budaya di Indonesia, Bharata, Jakarta.

Toelihere M.R., 1980 Buffalo Production and Develop ment in Indonesia pada Buffalo Production for Small Farm M.H. Tetangco, ed. FFTC Book Se ries, 15 Jan. Taipei $39-42$.

Usman A.M., 1971, Memperkenalkan Peternakan Kerbau Rawa (Swamp Buffalo) di Kalimantan Selatan, $P e$ nyuluhan/ Pendidikan Inspektorat Dinas Peternakan Propinsi Kalimantan Selatan, Banjarmasin.

Wiryosuhanto S.D., Purwandariyanto dan W. Ediyati, 1980, Peternakan Kerbau di Indonesia, Ditjennak Direktorat Bina Program, Jakarta 